\title{
Morphological and Quality Traits Performance of the Fruits of Wild Pomegranate (Punica granatum L.) in Himachal Pradesh
}

\author{
Thiyam Jefferson Singh* and Tara Gupta
}

Dr. Y. S. Parmar University of Horticulture and Forestry Nauni, Solan, Himachal Pradesh (173 230), India

\section{Corresponding Author}

Thiyam Jefferson Singh

e-mail: lampardleo@gmail.com

\author{
Article History \\ Article ID: 3 C0997 \\ Received in 04 ${ }^{\text {th }}$ November, 2017 \\ Received in revised form $25^{\text {th }}$ April, 2018 \\ Accepted in final form $24^{\text {th }}$ May, 2018
}

\begin{abstract}
Present investigations were carried out on wild pomegranate (Punica granatum L.) in three locations spread across two districts of Himachal Pradesh. The extent of genetic variability, heritability and genetic advance with respect to fruit morphology (i.e. fruit width, fruit length, fresh weight of fruit, fresh weight of rind, fresh seed weight with pulp and fresh seed weight without pulp and quality traits (i.e TSS, total sugar, reducing sugar, non-reducing sugar, acidity and ascorbic acid) in the fruits of fifteen wild pomegranate genotypes from Tatool, Narag and Daro Deohria were studied. Fruit width, length, fresh weight of fruit, fresh weight of rind, TSS, total sugar, reducing sugar, non-reducing sugar and ascorbic acid were recorded with high heritability. Thus, selection of progenies based on performance would be effective for these characters. All the parameters were positively and significantly correlated with each parameter. Fresh weight of seed with aril had highly significant and positive correlation with fruit width, fruit length, total sugar and reducing sugar. Therefore, emphasis should be given to these characters while selecting a genotype for enhancing yield and fruit size in pomegranate. On the basis of desirable parameters, best individuals will be selected and tree improvement programme can be taken up for further studies.
\end{abstract}

Keywords: Morphological, quality, wild pomegranate, Punica granatum L.

\section{Introduction}

Wild pomegranate (Punica granataum) belongs to family Punicaceae, is native to Iran (Persia) and is one of the oldest fruit known to mankind. It has been traditionally cultivated since ancient times under diverse agro-climatic conditions. Pomegranate is a favourite fruit of tropical, subtropical and arid regions (Pareek, 1981). Major pomegranate growing areas are Maharashtra, Karnataka, Andhra Pradesh, Gujarat, Tamil Nadu and Rajasthan. Maharashtra is the major pomegranate growing state. It grows wild in Western Himalayan regions that include states like Himachal Pradesh, Jammu and Kashmir and Uttarakhand (Pandey et al., 2008). Some wild types pomegranate also found in foot hills of Himachal Pradesh which can be exploited for anardana purpose (Singh and Singh, 2006). In Himachal Pradesh, it is spread evenly in Solan, Sirmour, Mandi, Shimla, Kullu and Chamba districts (Bhrot, 1998). Darlaghat is one of the most important centres of wild pomegranate growing region in Himachal Pradesh which is about $50 \mathrm{~km}$ from Shimla (Thakur et al., 2011). It is deciduous in temperate ecosystem and an evergreen or partially deciduous in tropical and subtropical conditions. Orchards can be established at higher altitude including mid hills and foothills. Pomegranate can be grown on a wide range of soils but is found to do well on light and medium type of soil. The soil should be well drained. Fruit quality and colour development in light soils is good but poor in heavy soils. Pomegranate has versatile adaptability, drought resistance; low maintenance cost, steady and high yields of the crop. The pomegranate fruit has therapeutic value, good keeping quality and high export potential and is mainly grown for table purpose. The juicy pulp in the arils (seeds) varies from almost colorless to blood red. The seeds in some pomegranate varieties are very soft, while in others they are large and hard. Whole pomegranate fruits contain $45-61 \%$ juice, while arils yield $76-85 \%$ juice (Patil and Sanghavi, 1980). Pomegranate fruits are the good sources of carbohydrates and minerals such as $\mathrm{Ca}$, Fe and $\mathrm{S}$ and a moderate source of pectin. Glucose and fructose are the main sugars in pomegranate. These beneficial effects may be related to its high antioxidanta ctivity resulting from the presence of a variety of biologically active compounds (Aviram, 2002; Halvorsen et al., 2002). The edible part of the fruit contains considerable amount of acids, sugar, vitamins, polysaccharides, polyphenols and minerals (Gil et al., 2001; Kulkarni et al., 2004). In spite of various pomegranate cultivars grown in different regions of India, there is no known cultivar for mid to high temperate conditions. There is a need to conduct study on the selected trees for genetic characterization and breeding potential to harness genetic 
values through progeny evaluation and multiplication.

\section{Materials and Methods}

The study was conducted in the Department of Tree Improvement and Genetic Resources, College of Forestry, Dr. Y. S. Parmar University of Horticulture and Forestry, Nauni, Solan, Himachal Pradesh. Three sites were selected for study of physiological and chemical characteristics of wild Punica granatum L. The sites selected were Tatool (L1) in district Solan and Narag (L2) and Daron (L3) in district Sirmour (Table 1). From each selected site, five medium sized tree were selected and marked. Yield attributing traits like fruit length, breadth, fruit weight and quality parameters viz; acidity, TSS, were recorded. At the time of fruit harvest five fruits from each plant collected randomly for physico-chemical analysis. Size of fruit was recorded with the help of digital calliper. TSS was determined with the help of hand refractometer. Titrable acidity was estimated by titrating the known volume of juice with $0.1 \mathrm{~N} \mathrm{NaOH}$, using phenolphthalein as indicator (A.O.A.C., 1998). Meterological parameters like temperature, rainfall and relative humidity were also recorded during fruiting period for interpretation of experimental results. Single tree constituted an experimental unit and each genotype was replicated three times. For statistical analysis RBD design for field parameters and CRD design for laboratory parameters was followed.

Three selected study sites of wild pomegranate (Punica granatum L.)

\begin{tabular}{lccc}
\hline Sites & Latitude & Longitude & Code \\
\hline Tatool & $30^{\circ} 86^{\prime} \mathrm{N}$ & $77^{\circ} 14^{\prime} \mathrm{N}$ & $\mathrm{L} 1$ \\
Narag & $30^{\circ} 87^{\prime} \mathrm{N}$ & $77^{\circ} 18^{\prime} \mathrm{N}$ & $\mathrm{L} 2$ \\
Daron & $30085^{\prime} \mathrm{N}$ & $77020^{\prime} \mathrm{N}$ & L3 \\
\hline
\end{tabular}

\section{Results and Discussion}

The analysis of variance indicated high and significant differences in quantitative attributes, viz., Fruit width, length and TSS ( $\left.{ }^{\circ} \mathrm{Brix}\right)$. The bio-metrical components of genetic variability measured in terms of genotypic coefficient of variation (GCV), phenotypic coefficient of variation (PCV), heritability (broad sense), genetic advance (GA) as percentage of mean (genetic gain) based on quantitative characters of the open pollinated wild pomegranate trees are given in Table 3. The results indicate a wide range of variability in fruit width, fruit length, fresh weight of fruit, fresh weight of rind, fresh weight of seed with aril and fresh weight of seed without aril. The genetic coefficient of variation (GCV \%) ranged from $3.24 \%$ in Ascorbic acid to 20.39 in Non-reducing sugar and phenotypic coefficient of variation (PCV\%) ranged from 3.81\% in Ascorbic acid to 24.89 in Non-reducing sugar .

The mean performance of the fruits of open pollinated flowers of wild pomegranate trees depicted wide range of variation and that is not only for fruit morphology (i.e. fruit width, fruit length, fresh weight of fruit, fresh weight of rind, fresh weight of seed with aril and fresh weight of seed without aril) but also quality traits (i.e. TSS, total sugar, reducing sugar, non-reducing sugar, acidity and ascorbic acid). The most promising individuals were selected considering the important commercial characters, viz., fruit length and high TSS.

Absolute variability in different characters does not permit on deciding as to which character is showing the highest degree of variability. Therefore, estimates of phenotypic and genotypic variance and coefficient of variation become necessary. Maximum variation was shown in fruit length followed by fruit width, fresh weight of fruit, fresh weight of seed with aril and fresh weight of rind both at genotypic and phenotypic levels. In the present study, in general, the estimates of PCV were higher than GCV in all the characters but showed narrow differences (Table 2) implying that variability was due to genetic factors. The highest estimates of PCV and GCV were shown by nonreducing sugar and fresh seed with pulp, respectively. Both the estimates were moderate for reducing sugar. These results indicate that high magnitude of genetic variability existed for the non-reducing sugar contributing traits, offering a good opportunity for improvement through selection. This is in consonance with the findings of Karale and Desai (1998). Although GCV helps to measure the genetic variability in a character, it is not possible to partition the heritable variation with this alone. Burton (1952) suggested that GCV together with heritability estimates would give the best results of the amount of genetic advance to be expected from a selection. The magnitude of heritability indicated the reliability of the genotypes with which they can be identified for their phenotypic expression. High estimates of heritability were obtained for fresh weight of fruit and quality components, whereas it was moderate for fruit quality characters. The heritability was very high for fresh weight of fruit (0.84) followed by fresh weight rind (0.79), ascorbic acid (0.72) and total sugar (0.69). In the present studies, high heritability in fresh weight of fruit and quality characters may be due to low influence of nongenetic factors on the expression of the traits. Hanshe et al. (1972) in peach, and Karale and Desai (1998) in pomegranate also observed similar trends. Thus, selection of genotypes for these characters can be done on the basis of its own phenotypic performance. The heritability variation can be estimated with greater degree of accuracy when heritability is studied along with genetic advance. A high heritability coupled with high genetic advance gives the most effective criteria for selection (Johnson et al., 1955). Genetic advance as percentage of mean (genetic gain) was high for fruit length (6.80) followed by fruit width (6.26) and fresh weight of fruit (4.99), whereas it was moderate for fresh weight rind and fresh weight of seed with aril. Low estimates of genetic gain were recorded for ascorbic acid and fresh weight of seed without aril. Manohar et al. (1981) also reported high estimates of GCV, heritability and genetic advance for fruit length, fresh weight of fruit and fruit length and suggested that improvement in these characters can be brought about by selection.

In the present study, high heritability estimates coupled with high genetic advance as percentage of mean were observed for fruit length and fruit width and fresh weight of fruit 


\begin{tabular}{|c|c|c|c|c|c|c|c|c|c|c|c|}
\hline \multirow[t]{2}{*}{ Characters } & \multicolumn{2}{|c|}{ Range } & \multirow[t]{2}{*}{ Mean } & \multirow[t]{2}{*}{$C D$} & \multirow[t]{2}{*}{$V p$} & \multirow[t]{2}{*}{ Vg } & \multirow{2}{*}{$\begin{array}{l}\text { Genotypic } \\
\text { coefficient } \\
\text { of variability }\end{array}$} & \multirow{2}{*}{$\begin{array}{l}\text { Phenotypic } \\
\text { coefficient of } \\
\text { variability }\end{array}$} & \multirow{2}{*}{$\begin{array}{c}\text { Herita- } \\
\text { bility }\end{array}$} & \multirow{2}{*}{$\begin{array}{l}\text { Genetic } \\
\text { advance }\end{array}$} & \multirow{2}{*}{$\begin{array}{l}\text { Genetic } \\
\text { gain (\%) }\end{array}$} \\
\hline & Min. & Max & & & & & & & & & \\
\hline $\mathrm{FW}(\mathrm{cm})$ & 36.72 & 59.92 & 46.17 & 2.67 & 29.23 & 16.44 & 8.78 & 11.71 & 0.56 & 6.26 & 13.57 \\
\hline $\mathrm{FL}(\mathrm{cm})$ & 35.12 & 59.56 & 46.98 & 2.71 & 31.8 & 18.6 & 9.18 & 12 & 0.58 & 6.8 & 14.46 \\
\hline FWF (g) & 39.32 & 49.27 & 43.58 & 0.86 & 8.32 & 6.99 & 6.07 & 6.62 & 0.84 & 4.99 & 11.45 \\
\hline FWR (g) & 10.45 & 17.41 & 13.55 & 0.55 & 2.66 & 2.11 & 10.72 & 12.03 & 0.79 & 2.67 & 19.68 \\
\hline FSA (g) & 9.34 & 24.64 & 14.46 & 1.7 & 7.84 & 2.64 & 11.23 & 19.37 & 0.34 & 1.94 & 13.42 \\
\hline FSWA (g) & 2.65 & 5.24 & 3.62 & 0.37 & 0.31 & 0.06 & 6.89 & 15.26 & 0.2 & 0.23 & 6.41 \\
\hline Tss ( ${ }^{\circ}$ Brix) & 12.1 & 18.3 & 15.97 & 0.65 & 2.08 & 1.31 & 7.17 & 9.03 & 0.63 & 1.87 & 11.72 \\
\hline TS (\%) & 8.55 & 13.4 & 11.46 & 0.46 & 1.22 & 0.84 & 7.99 & 9.62 & 0.69 & 1.57 & 13.67 \\
\hline RS (\%) & 5.5 & 9.89 & 7.9 & 0.53 & 1.22 & 0.72 & 10.74 & 13.98 & 0.59 & 1.34 & 17 \\
\hline NRS (\%) & 1.75 & 6.21 & 4.39 & 0.47 & 1.19 & 0.8 & 20.39 & 24.89 & 0.67 & 1.51 & 34.4 \\
\hline Acidity (\%) & 3.09 & 6.82 & 5.38 & 0.62 & 0.95 & 0.24 & 9.19 & 18.06 & 0.26 & 0.52 & 9.63 \\
\hline $\begin{array}{l}\text { AA (mg } 100 \\
\left.g^{-1}\right)\end{array}$ & 16.95 & 19.72 & 18.53 & 0.28 & 0.5 & 0.36 & 3.24 & 3.81 & 0.72 & 1.05 & 5.68 \\
\hline
\end{tabular}

FW: Fruit width (cm); FL: Fruit length (cm); FWF: Fresh weight of fruit (g); FWR: Fresh weight rind (g); FSA: Fresh weight of seed with aril (g) ; FSWA: Fresh weight of seed without aril (g); TS: Total sugar (\%); RS: Reducing sugar (\%); NRS: Non reducing sugar (\%); AA: Ascorbic acid (mg $\left.100 \mathrm{~g}^{-1}\right)$

indicating that the heritability for these characters might be due to additive gene effects. Further, these characters could be considered reliable selection indices. The characters with high heritability coupled with low genetic advance were recorded for ascorbic acid, total sugar and non-reducing sugar indicating that these characters are controlled by nonadditive gene action. Thus, the reliability of improvement in these characters through selection would be relatively low and may require higher selection pressure. Genotypic correlation coefficient, in general, were greater in magnitude than the corresponding phenotypic ones (Table 3), indicating that there was an inherent association among various characters and that phenotypic expression of correlation was lessened under the influence of environment. Fruit width showed highly significant positive correlation with respect to fruit weight and fruit length suggesting that these characters are the most important yield contributing components and that effective improvement in fruit yield can be achieved through selection based on these traits. Fruit length had highly significant and positive correlation with fresh weight

\begin{tabular}{|c|c|c|c|c|c|c|c|c|c|c|c|c|}
\hline $\begin{array}{l}\text { Charac- } \\
\text { ters }\end{array}$ & FW & $\mathrm{FL}$ & FWF & FWR & FSA & FSWA & TSS & TS & RS & NRS & Acidity & $A A$ \\
\hline FW & 1.000 & $0.990^{* *}$ & $0.995^{* *}$ & $0.953^{* *}$ & $0.935^{* *}$ & $0.940^{* *}$ & $0.924^{* *}$ & $0.942^{* *}$ & $0.944^{* *}$ & $0.781^{* *}$ & $0.767^{* *}$ & $0.798^{* *}$ \\
\hline $\mathrm{FL}$ & & 1.000 & $0.992^{* *}$ & $0.973^{* *}$ & $0.952^{* *}$ & $0.963^{* *}$ & $0.944^{* *}$ & $0.958^{* *}$ & $0.954^{* *}$ & $0.840^{* *}$ & $0.829^{* *}$ & $0.848^{* *}$ \\
\hline FWF & & & 1.000 & $0.956^{* *}$ & $0.942^{* *}$ & $0.948^{* *}$ & $0.928^{* *}$ & $0.944^{* *}$ & $0.944^{* *}$ & $0.804^{* *}$ & $0.787^{* *}$ & $0.815^{* *}$ \\
\hline FWR & & & & 1.000 & $0.980^{* *}$ & $0.996^{* *}$ & $0.974^{* *}$ & $0.966^{* *}$ & $0.962^{* *}$ & $0.829^{* *}$ & $0.834^{* *}$ & $0.823^{* *}$ \\
\hline FSA & & & & & 1.000 & $0.990^{* *}$ & $0.973^{* *}$ & $0.958^{* *}$ & $0.970^{* *}$ & $0.853^{* *}$ & $0.864^{* *}$ & $0.845^{* *}$ \\
\hline FSWA & & & & & & 1.000 & $0.974^{* *}$ & $0.960^{* *}$ & $0.962^{* *}$ & $0.830^{* *}$ & $0.837^{* *}$ & $0.819^{* *}$ \\
\hline Tss & & & & & & & 1.000 & $0.992^{* *}$ & $0.991^{* *}$ & $0.859^{* *}$ & $0.863^{* *}$ & $0.858^{* *}$ \\
\hline TS & & & & & & & & 1.000 & $0.994^{* *}$ & $0.858^{* *}$ & $0.856^{* *}$ & $0.868^{* *}$ \\
\hline RS & & & & & & & & & 1.000 & $0.852^{* *}$ & $0.852^{* *}$ & $0.863^{* *}$ \\
\hline NRS & & & & & & & & & & 1.000 & $0.989^{* *}$ & $0.994^{* *}$ \\
\hline Acidity & & & & & & & & & & & 1.000 & $0.977^{* *}$ \\
\hline AA & & & & & & & & & & & & 1.000 \\
\hline
\end{tabular}


of fruit, fresh weight rind and fresh weight of seed with aril. Desai et al. (1992) observed similar trends for character association between fruit yield components in pomegranate. All the characters were positively correlated. It indicates that in pomegranate the progenies producing more fruits have also genetically potential to give bigger and better fruits. On the basis of the analysis of quantitative characters for component of variability, it is evident that fresh weight of fruit, fresh weight rind and fresh weight of seed with aril deserves due weightage while formulating selection strategies for improvement in pomegranate. Thus, selection of superior types based on fruit length components would be effective after ensuring the acceptable fruit quality components in the breeding material. For selection of desirable individuals within a heterozygous population developed through combination of heterozygous parents/population, selection of desirable individuals can be done on the basis of deviation from the mean of the population. Therefore, the best individuals under heterozygous population having better fruit quality and yield performance could be identified for further clonal evaluation to select the most promising types. Data revealed that a considerable range of variations exits in all the fruit quality characters among the individuals and is in accordance with Samadia and Pareek (2006). This type of situation suggests that the best performing individuals having excellent fruit quality can be further tested for high yield potential after multiplication.

\section{Conclusion}

High heritability estimates coupled with high genetic advance as percentage of mean were observed for fruit length and fruit width and fresh weight of fruit indicating that the heritability for these characters might be due to additive gene effects. On the basis of the analysis of quantitative characters for component of variability, it is evident that fresh weight of fruit, fresh weight rind and fresh weight of seed with aril deserves due weightage while formulating selection strategies for improvement in pomegranate. Thus, selection of superior types based on fruit length components would be effective after ensuring the acceptable fruit quality components in the breeding material.

\section{References}

AOAC., 1998. Official methods of analysis. Association of Official Analytical Chemists. Washington. USA.

Aviram, M., 2002. Pomegranate juice is a major source for polyphenolic flavonoids and it is most potent antioxidant against LDL oxidation and atheroselerosis. Free Radical Biology and Medicine 36, 71-73.

Bhrot, N. P., 1998. Genetical analysis of wild pomegranate (Punica granatum L) for some growth ecological and quality characters. Phd. Thesis, Dr. Y. S. Parmar University of Horticulture and Forestry, Solan, India, 102.

Burton, G.W., 1952. Quantitative inheritance in grasses. In Proceedings of 6th International Grassland Congress 17-23 August 1952. Pennsylvania State College.
Desai, U.T., Jagtap, D.B., Choudhari, S.M., 1992. Relationship between growth characteristics and yield potential in pomegranate. Annual Arid Zone 31, 299-300.

Gil, M.I., Barberan F.A.T., Hess P., Holcroft D.M., Kader A.A., 2001. Antioxidant acivity of pomegranate juice and its relationship with phenolic composition and processing. Journal of Agricultural and Food Chemistry 48, 45814589.

Halvorsen, B.L., Holte, K., Myhrstad, M.C.W., Barikmo, I., Hvattum, E., Remberg, S.F., Wold, A.B., Haffner, K., Baugerod, H., Andersen, L.F., Moskaug, J.O., Jacobs, D.R., Blomhoff, R., 2002. A systematic screening of total antioxidant in dietary plants. Journal of Nutrition 132, 461-471.

Hanshe, D.E., Hesse, C.O., Beres, V., 1972. Estimates of genetic and environmental effects on several traits in peach. Journal of the American Society for Horticultural Science 97, 76-79.

Johnson, H.W., Robinson, H.F., Comstock, R.E., 1955. Estimates of genetic and environmental variability in soybean. Agronomy Journal 47, 314-18.

Karale, A.R., Desai, U.T., 1998. Studies on heritability and genetic advance for certain fruit characters in pomegranate (Punica granatum L.). Journal of Maharashtra Agricultural Universities 85, 599-600.

Kulkarni, A.P., Aradhya, S.M., Divakar, S., 2004. Isolation and identification of radical scavenging antioxidant punicalogin from pith and capillary membrane of pomegranate food. Food Chemistry 87, 551-557.

Manohar, M.S., Tikka, S.B., Lal, N., 1981. Phenotypic variation and its heritable components in some biometrical characters in pomegranate (Punica granatum L.). Indian Journal of Horticulture 38, 187-90.

Pandey, A., Tomer, A.K., Bhandari, D.C., Pareek, S.K., 2008. Towards collection of wild relatives of crop plants in India. Genetic Resources and Crop Evolution 55, 187-202.

Pareek, O.P., 1981. In Proceedings of National Workshop on Arid Zone Fruits held at HAU, Hissar.

Patil, A.V., Sanghavi, K.U., 1980. Performance of different varieties of pomegranate (Punica granatum L.) in dry regions of Western Maharashtra. Annals of arid zone 19, 485.

Samadia, D.K., Pareek, O.P., 2006. Studies on genetic variability and varietal performance in pomegranate under hot arid environment. Indian Journal of Horticulture 63(2), 126-132.

Singh, D.B., Singh R.S., 2006. Diversity of wild pomegranate in Himachal Pradesh. Progressive Horticulture 38(1), 49-52.

Thakur, N.S., Dhaygude, G.S., Gupta, A., 2011. Physicochemical characteristics of wild pomegranate fruits in different locations of Himachal Pradesh. International Journal of Farm Sciences 1(2), 37-44. 